\title{
Correction to: Massive Hemothorax Due to Intrathoracic Herniation of the Gastric Remnant After Roux-en-Y Gastric Bypass with Concurrent Hiatal Hernia Repair
}

\author{
Isabel Mora Oliver ${ }^{1} \cdot$ Raquel Alfonso Ballester $^{1}$ (D) Gabriel Kraus Fischer $^{1} \cdot$ Ana Benítez Riesco $^{1}$ • \\ Norberto Cassinello Fernández ${ }^{1}$ • Joaquín Ortega Serrano ${ }^{1}$
}

Published online: 3 June 2020

(C) Springer Science+Business Media, LLC, part of Springer Nature 2020

\section{Correction to: Obesity Surgery https://doi.org/10.1007/s11695-020-04679-x}

The references were incorrectly ordered during production.

The correct Reference 4 is:

4. Aly A, Mun J, Jamieson GG, et al. Laparoscopic repair of large hiatal hernias. Br J Surg. 2005;92:648-53.

From Reference 4 forward, all references are increased by one number and appear as below:

5. Bakhos CT, Patel SP, Petrov RV, Abbas AE. Management of paraesophageal hernia in the morbidly obese patient. Thorac Surg Clin 2019; 29: 379-386.

6. Hefler J, Dang J, Mocanu V, Switzer N, Birch DW, Karmali S. Concurrent bariatric surgery and paraesophageal hernia

The online version of the original article can be found at https://doi.org/ $10.1007 / \mathrm{s} 11695-020-04679-\mathrm{x}$

Raquel Alfonso Ballester

raquelalfonsoballester@msn.com

Isabel Mora Oliver

isab_mora@hotmail.com

Gabriel Kraus Fischer

fischerkrausg@gmail.com

Ana Benítez Riesco

ana.br94@gmail.com

Norberto Cassinello Fernández

cassinello73@hotmail.com

Joaquín Ortega Serrano

joaquin.ortega@uv.es

1 General Surgery Department, Endocrine and Bariatric Surgery Division, Clinic University Hospital of Valencia, University of Valencia, Av. de Blasco Ibáñez, 17, 46010 Valencia, Spain repair: an analysis of the Metabolic and Bariatric Surgery Association Quality Improvement Program (MBSAQIP) database. Surg Obes Relat Dis 2019; 15 (10): 1746-1754.

7. Saber AA. Gastric migration after bariatric surgery. Obes Surg 2019; 29 (7): 2307-2308.

8. Caceres M, Eid GM, McCloskey CA. Recurrrent paraesophageal hernia presenting as obstruction of roux lim after Roux-en-Y gastric bypass. Surg Obes Relat Dis (2010);6: 197.

9. Cardaci MB, Keuleneer R, Massaarani F. Hiatal hernia containing the alimentary limb and the gastric pouch: a rare cause of small bowel obstruction after Roux-en-Y gastric bypass. Surg Obes Relat Dis 2017; 13(11): 1929-31.

10. Iannelli A, Kassir R, Schneck AS, Martini F, Gugenheim J. Hiatal hernia of the Rouxen- Y gastric bypass pouch 8 years after surgery. Obes Surg 2014; 24(9): 1494-9.

11. Borbély Y, Kröll D, Nett PC, Moreno P, Tutuian R, Lenglinger J. Radiologic, endoscopic and functional patterns in patients with symptomatic gastroesophageal reflux disease after Roux-en-Y gastric bypass. Surg Obes Relat Dis 2018.

12. Clapp B, Vo LU, Lodeiro C, Harper B, Montelongo S, Lee I et al. Late-term hiatal hernia after gastric bypass: an emerging problem. Surg Obes Relat Dis 2020; 16 (4): 471-475.

13. Kohn GP, Price RR, DeMeester SR, Zehetner J, Muensterer OJ, Awad Z et al. Guidelines for the management of hiatal hernia. Surg Endosc 2013; 27 (12): 4409-28.

14. Memon MA, Memon B, Yunus RM, Kahn S. Suture cruroplasty versus prosthetic hiatal herniorrhaphy for large hiatal hernia: a meta-analysis and systematic review of randomized controlled trials. Ann Surg. 2016;263:258-66.

The final line of the Discussion, just before the Conclusions, should read:

"...should be left to the discretion of the surgeon [14]." 